\title{
Agricultural Mechanization Status for Some Crops in Irrigated Sector in River Nile State, Sudan
}

\author{
Alaeldin M. E. Awadalla ${ }^{1}$, Kang Sukwon ${ }^{2}$, Kwon Taek-Ryoun ${ }^{3}$ \& S. A. Haider ${ }^{4}$ \\ ${ }^{1}$ Agricultural Engineering Research Program, Hudeiba Research Station, Agriculture Research Corporation, \\ Sudan \\ ${ }^{2}$ Energy \& Environmental Engineering Division, National Institute of Agricultural Sciences, Korea \\ ${ }^{3}$ Korea-Africa Food \& Agriculture Cooperation Initiative, Korea \\ ${ }^{4}$ Socio-economic Research Program, Hudeiba Research Station, Agriculture Research Corporation, Sudan \\ Correspondence: Alaeldin M. E. Awadalla, Agricultural Engineering Research Program, Hudeiba Research \\ Station, Agriculture Research Corporation, Sudan. Tel: 249-915-562-907. E-mail: alaeldinelhassan@yahoo.com
}

Received: April 15, 2019

doi:10.5539/jas.v11n13p127
Accepted: June 14, 2019 Online Published: August 15, 2019

URL: https://doi.org/10.5539/jas.v11n13p127

\begin{abstract}
Agricultural mechanization and it is impact on agricultural productivity was studied by many authors in different areas in the world. Irrigated agriculture in the Sudan, have played a significant role in expanding agricultural mechanization, and the major mechanized operation is the land preparation, operations such as planting, spraying, fertilizer application, mechanical weeding and harvesting are still largely carried out manually. A baseline survey on mechanization status was implemented in River Nile State, focuses on mechanization status for production of wheat as strategic crop, legumes as food crops, onion and alfalfa as cash crops in smallholder farms. The analysis of respondents answers show that tillage operation has the high percent $(90.5-93.3 \%)$ of mechanical power among other operations for production of the selected crops, where wheat has considerable percent of using mechanical power in sowing and harvesting operations compare to the three rest crops. For legumes and alfalfa broadcasting of seeds for sowing and cutting and binding at harvest operations, still manual activity prevailing, where for onion transplanting are $100 \%$ carried out manually. The mechanization level range between $0.2-0.58$, which reflect the less number of tractors to the cultivated areas in the state. Concerning the mechanization index as the ratio of mechanical power to the total power input in term of $\mathrm{MJ} / \mathrm{ha}$ for each crop range from $0.03-0.07$, shows that manual and animal power still exerted to produce such crops.
\end{abstract}

Keywords: survey, mechanization level, index, crops, irrigated sector, river Nile state

\section{Introduction}

The status of agricultural mechanization and its impact in increasing the agricultural and labour productivity were studied by some authors, Adnan et al. (2017) study mechanization index and it is impact on productivity with socio-economic factors, Olaoye and Adekanye (2014) investigated mechanization index in some settlement schemes in Nigeria, Patrick and Tapela (2002) concluded from their reviewed of agricultural mechanization in Botswana, animal draft power is still use with greatest intervention in mechanization by the government, Krishnasreni and Thongsawatwong (2004) concluded that agricultural mechanization has important role in improving production during economic crisis faced Thailand. Zeren (1991) express that agricultural mechanization has not direct effect on increasing farm yield, but it helps to use modern technologies in agriculture, eases working conditions in farms and spare manpower to other activities in other sectors, but Singh (2001) for analysis of data from 1950-1997, shows that the yield is positively related to power available in both time and space, and Chen, Yu, Chang, and Hsu (2008) revealed that mechanization utilization has caused to agricultural productivity growth during 1990-2003. Power availability in different countries was reviewed by Giles (1975), demonstrated that productivity was positively correlated with potential unit farm power, and the impact of tractorization on the productivity of land and economic growth was assessed by National Centre for Agricultural Mechanization [NCAER] (1981). Khadir and Adu-Hamed (2002) analyzes the factors that affect adoption rate of mechanization in Jordan, where Jingen and Qishuo (2000) study development speed of farm mechanization in Jiangsu. Rijk (1989) suggested computer software (MECHMOD) for the formulation of 
strategy for mechanization policy based on economics of use of animate and mechanical power for different field operations.

Irrigated agriculture in Sudan, as the large scale irrigation scheme such as the Gezira, initiated in 1925 over 0.9 million hectares, with the irrigation system is the highest levels of irrigation in the region, that since the 1940s have to play a significant role in expanding agricultural mechanization, till that time the major full mechanized operation is the land preparation, with low level of mechanization for other secondary operations (Figure 1). At the same time, in nearly all the new other irrigation schemes in the other parts of the Sudan, operations such as planting, spraying, fertilizer application, mechanical weeding and harvesting are still largely carried out manually. This show that farm power in the Sudan irrigated agriculture relies to some extent on human muscle power that depend on the traditional hoe and other hand tools for farm operations, and to tractors in land preparation and threshing.

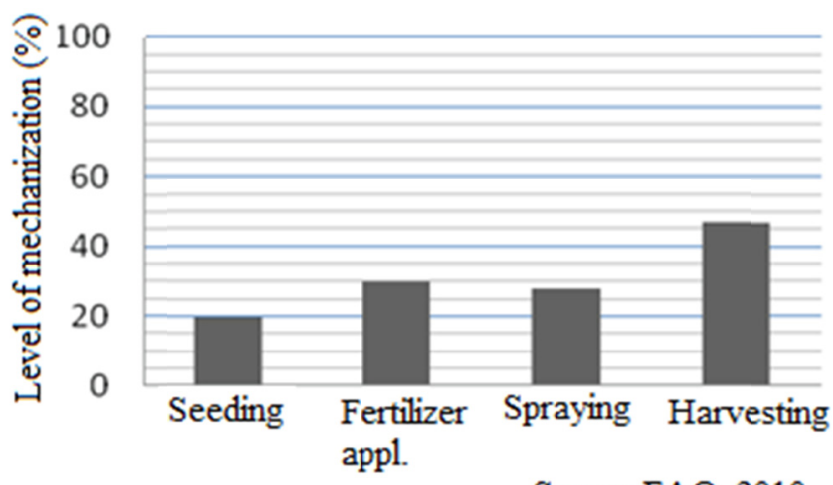

Source:FAO, 2010

Figure 1. Mechanization level of secondary agricultural operations in the Gezira, Sudan

Food and Agriculture Organization [FAO], 2013) reviewed the agricultural mechanization situation in the Sudan with other six East African countries (Burundi, Ethiopia, Kenya, Rwanda, Tanzania and Uganda), to assess factors that seem to have accelerated agricultural mechanization and those that seem to have hindered it, and the roles of the public and private sectors that can be known, it was realized during the assessment there is very limited data and information on mechanization in the Sudan and the other six countries; this must be constraining the planning and development of agricultural mechanization. Also, Khalid (2013) found that the agricultural production in the Sudan are impeded by various challenges, one of them is absence of mechanization and modern technologies, in addition, the unsuitable application and low level of mechanized operations for crops production lead to high losses.

Therefore, some official attempts depending on scatter discuss workshops paper and routine annual agricultural reports, try to enhance technology intervention in irrigated sector, as in the Sudan Strategic Quarter-Centennial Plan, in medium short term, one thematic program for intervention of Technology Transfer and Extension is integrated mechanization (Abdelrazig Fatih, Abdelatif, \& Hassan, 2004). The Sudanese government wants to convert its agriculture into an agri-business entity through Agricultural Revival Strategy (Government of Sudan, 2008), one of the programs under the strategy focuses on enhancing the capacity of technology transfer and extension services, unfortunately, considering the role of mechanization only on one program that is of generalizing mechanical harvesting of crops mainly wheat in irrigated and sorghum in rain fed sectors (Igbal et al, 2016).

For smallholder farmers, Mrema, Kienzle, and Mpagalile (2018) cited there are suitable mechanization options and opportunities, but realistic consideration needs to be given to some key success factors, namely, effective demand, economic use rates, efficient machinery and equipment supply chains and services. The objective of this baseline survey is about to measure the level of mechanization for some major crops in the irrigated sector for smallholder farmers in River Nile State, to assess and find out the appropriate type of the mechanization according to the actual smallholder farmer's needs, therefore, to give mechanization of smallholder farm operations more systematic approach for sustainability of production, as smallholder farmers consider are the main producers of the world's food and they will have to increase production by up to 100 percent by 2050 to feed the growing population (Brian \& Josef, 2017), and the application of mechanical technology and increased 
power to agriculture, as a means to enhance the productivity of human labour up to 500 times in comparison to agriculture without mechanization (Mazoyer, 2001).

\section{Materials and Methods}

River Nile State, which is the survey study site (Figure 2), has area about 122.1 thousand square Kilometres, with arable estimated land about 1382000 hectares, the estimation of population according to the growth rate of the last census in 2008 about 1472257 persons in 2017, with average population density is about 12 people per $\mathrm{km}^{2}$. The agricultural farming system in the state is irrigated by pumping from Nile and Atbera rivers or under-ground water; there are three growing seasons, winter, summer and fall. A preliminary data related to the areas and numbers of farmers were collected for a number of schemes distributed along and far the two banks of the Nile and Atbara rivers, in the five selected localities (state districts) out of seven as shown in Table 1.

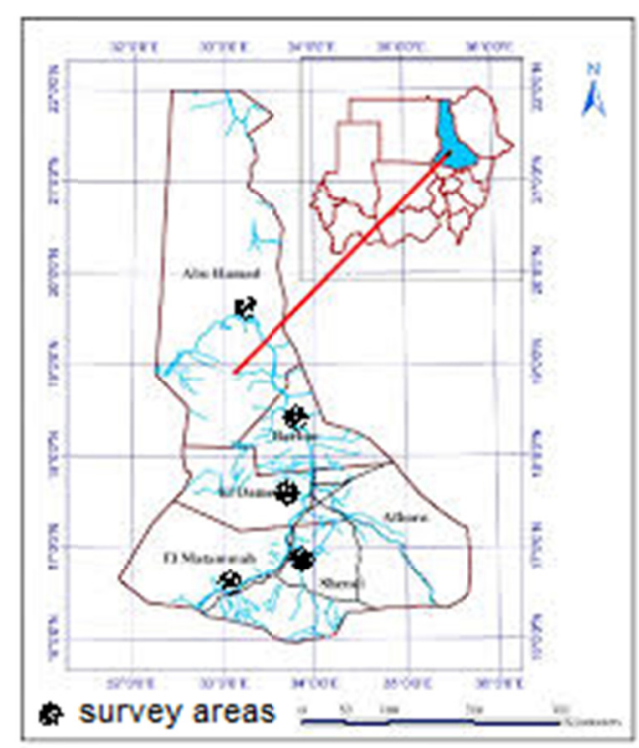

Figure 2. River Nile State map

Table 1. Schemes areas and estimated number of farmers in selected localities in River Nile State

\begin{tabular}{|c|c|c|c|c|c|c|}
\hline \multirow{2}{*}{ Locality } & \multirow{2}{*}{ Scheme No. } & \multicolumn{3}{|c|}{ Area (ha) } & \multirow{2}{*}{ No. of farmer } & \multirow{2}{*}{ Range ha/farmer } \\
\hline & & Total & Cultivated & As $\%$ from total & & \\
\hline Matama & 5 & 7985 & 7460 & 90.7 & 3978 & $0.7-18.5$ \\
\hline Shendi & 5 & 12088 & 6874 & 61.1 & 5684 & $0.2-2.3$ \\
\hline Ed-Damer & 7 & 45958 & 33734 & 81.1 & 10250 & $0.8-6.2$ \\
\hline Berber & 4 & 13230 & 6436 & 51.4 & 10650 & $0.3-2.5$ \\
\hline AbHamed & 6 & 26240 & 9930 & 57.9 & 4790 & $0.9-10$ \\
\hline
\end{tabular}

The survey implemented in the five selected localities, will be focus on mechanization status for tillage operations and planting, crop protection including mechanical weeding and chemical application, crop fertilization, two stage crops harvesting and direct harvesting, for wheat as strategic and legumes as food crops, onion and alfalfa as cash crops production. The method of collecting data, include primary data from research stations, extension and technology transfer centers, schemes headquarters, state ministry of agriculture departments, face to face interviews with individual farmers to fill the structured design questionnaire. The survey will undertake using a random sample of respondents depending on the important of the crop in each scheme. The primary data collection and the questionnaire filling data will be carried out by the researcher's team.

All the data collected for each operation for the selected crops in the five localities, were analysis using SPSS 21 software and Excel program, to calculate percent respondents of using animate and mechanical source of power. 
To estimate level of mechanization with reference to the total number of tractors available in each locality, using the formula suggested by Sharabiani and Ranjbar (2008) as below:

$$
\text { Mechanization level }=\text { Total real power/Cultivated area }
$$

Total power of existing tractors $($ TPET $)=$ Average power of one tractor $\times$ No. of working tractors

$$
\text { Total real power of tractors }(\text { TRPT })=T P E T \times C V(\text { Assume } \mathrm{CV}=0.75)
$$

For each operation to estimate energy input in term of $\mathrm{MJ} / \mathrm{ha}$, based on work rate in term of $\mathrm{h} / \mathrm{ha}$ of use animate or/and mechanical energy, considering that human muscle power equivalent of 74.6 watt was appropriate (S. Singh \& G. Singh, 1992), ox draft power was 450 watt (Tim, 2007), and $47.78 \mathrm{MJ} / \ell$ as energy equivalent value for diesel fuel (Cervinka, 1980), for each source power by using the following formulas:

$$
\begin{aligned}
& \text { Animate energy input }(\mathrm{MJ} / \mathrm{ha})=\text { No. of animate } \times \text { Work rate }(\mathrm{h} / \mathrm{ha}) \times \text { Animate power factor }(\mathrm{w}) \\
& \text { Mechanical energy input }(\mathrm{MJ} / \mathrm{ha})=\text { Work rate }(\mathrm{h} / \mathrm{ha}) \times \text { Average fuel use }(\ell / \mathrm{h}) \times \text { Fuel specific value }(\mathrm{MJ} / \ell)
\end{aligned}
$$

And to determine mechanization index by using the Equation 6 (Singh 2006; Raheleh, Alireza, \& Seyyed 2012):

$$
M I=E M /(E M+E A+E H)
$$

Where, $\mathrm{MI}=$ mechanization index, $\mathrm{EM}=$ energy use by mechanical, $\mathrm{EA}=$ energy use by animal and $\mathrm{EH}=$ energy use by human.

\section{Results and Discussion}

The analysis of respondents answers show that the mechanical plowing for tillage using tractor with 3bottom disk plow has the range of 88.2-93.3\% of mechanized operation among other operations for production of the selected crops, where wheat has considerable percent about $7.1 \%$ and $21.8 \%$ of using mechanical power in sowing and direct harvesting operations respectively, compare to the three rest crops (Table 1). For legumes (faba bean, common bean and chickpea) and alfalfa for collectively manual methods of sowing still prevailing with respondents percent $98.8 \%$, and $100 \%$ respectively, where for onion transplanting, digging are $100 \%$ and $97.4 \%$ respectively carried out manually (Table 1 ).

Based on the total number of tractors from technology transfer centers; private companies and farmers owner in each locality the mechanization level range between $0.2-0.58$ with average for the selected localities about 0.46 as shown in Table 2, this reflect the less number of tractors to the cultivated areas in the state. Follow inversely the procedure to calculate the mechanization level, assume to double the obtained average level of mechanization for the state, the number of tractors to be added accounted to about 884 tractors with nominal power of $75 \mathrm{hp}$, which is prevailing and appropriate for the farm size in the state.

Concerning the mechanization index as the ratio of mechanical power to the total power input in term of $\mathrm{MJ} / \mathrm{ha}$ it is about 0.07 for wheat and 0.03 for onion and alfalfa (Table 3), shows that manual and animal power still exerted to produce such crops. 
Table 1. Average respondent's percent for prevailing methods of farm operations in River Nile State

\begin{tabular}{|c|c|c|c|c|c|c|}
\hline \multirow{2}{*}{ Operation } & \multicolumn{6}{|c|}{ Localities Average Respondents Percent (\%) } \\
\hline & Method & Wheat & Legumes & Method & Onion & Alfalfa \\
\hline \multirow{4}{*}{ Plowing } & Tractor/3bottom disk plow & 91.6 & 88.2 & Tractor/3bottom disk plow & 93.3 & 90.5 \\
\hline & Animal drawn plow & 4.4 & 6.7 & Animal drawn plow & 4.5 & 3.1 \\
\hline & Tractor/heavy disk harrow & 4 & 3.5 & Tractor/heavy disk harrow & 2.2 & 6.4 \\
\hline & Tractor plow + animal plow & & 1.7 & & & \\
\hline \multirow{4}{*}{ Harrowing } & Not practice & 28.5 & & Not practice & & 37.3 \\
\hline & Animal plow & 9.7 & 11.6 & Animal plow & 5.3 & 7.3 \\
\hline & Tractor/light disk harrow & 61.4 & 88.4 & Tractor/light disk harrow & 94.7 & 55.1 \\
\hline & Walking tractor & 0.6 & & Walking tractor & & 0.3 \\
\hline & Animal Leveler & 7.3 & 6.2 & Animal Leveler & 5.3 & 5 \\
\hline \multirow{5}{*}{ Leveling } & Tractor Leveler & 75 & 82.5 & Tractor Leveler & 80.9 & 85 \\
\hline & Wasoog $^{1}$ & 0.3 & 2.6 & Wasoog & 1.7 & 1.7 \\
\hline & Tractor laser leveler & 6.5 & 2.6 & Tractor laser leveler & 0.6 & 2 \\
\hline & Tractor Leveler + wasoog & 0.3 & 3.5 & Tractor Leveler + wasoog & 2.4 & 0.9 \\
\hline & Tractor Leveler + Animal Leveler & 10.7 & 2.6 & Animal Leveler + wasoog & 9.1 & 5.4 \\
\hline & On flat & 4.1 & & On flat & & 52.4 \\
\hline \multirow{4}{*}{ Make Ridge } & Manual & 2.7 & 5.7 & Manual & 8.6 & 5.8 \\
\hline & Animal Ridger & 12.5 & 23.4 & Animal Ridger & 9.6 & 6.2 \\
\hline & Tractor Ridger & 80.4 & 70.9 & Tractor Ridger & 81.8 & 35.6 \\
\hline & Walking tractor & 0.3 & & & & \\
\hline \multirow{6}{*}{ Sowing } & Manual broadcasting & 89.1 & 86.3 & Manual broadcasting & & 98.6 \\
\hline & Tractor broadcaster & 5.7 & 0.9 & Broadcast behind animal plow & & 1.4 \\
\hline & Seed drill & 1.4 & & Manual transplanting & 100 & \\
\hline & Broadcast behind animal plow & 3.9 & 10.3 & & & \\
\hline & Row planter & & 0.4 & & & \\
\hline & Dibbling & & 2.2 & & & \\
\hline \multirow{6}{*}{ Weeds Control } & Manual & 13.3 & 20.1 & Manual & 17.1 & \\
\hline & Knapsack sprayer & 62.2 & 62.7 & Knapsack sprayer & 61.8 & \\
\hline & knapsack sprayer + manual & 19.3 & 15.9 & knapsack sprayer + manual & 20.9 & \\
\hline & Not practice & 5.3 & & Tractor boom sprayer & 0.2 & \\
\hline & Hand held motorized cutter & & 0.9 & & & \\
\hline & Tractor boom sprayer & & 0.5 & & & \\
\hline \multirow{2}{*}{ Urea applic. } & manual & 99.7 & & Manual & 99.7 & 100 \\
\hline & Tractor broadcaster & 0.3 & & Not applied & 0.3 & \\
\hline \multirow{7}{*}{ Harvesting } & Manual cutting & 78.1 & 100 & Manual digging/cutting & 97.4 & 99.4 \\
\hline & Manual binding and/or collect & 78.1 & 100 & Digging by animal plow & 1.2 & \\
\hline & Manual threshing & 6.2 & 12.8 & Tractor digger & 1.4 & \\
\hline & Animal threshing & 0.4 & 0.9 & Tractor mower & & 0.6 \\
\hline & Stationary thresher & 71.6 & 86.3 & & & \\
\hline & Combine harvester ${ }^{2}$ & 10 & & & & \\
\hline & Combine harvester ${ }^{3}$ & 11.8 & & & & \\
\hline
\end{tabular}

Note. 1 = traditional wooden leveler; 2 = packing in sacks; 3 = unload yield on plastic sheet on soil.

Table 2. Estimated mechanization level for each locality in River Nile State in the Sudan

\begin{tabular}{lllllll}
\hline Item & Matama & Shendi & Damer & Berber & Ahamed & Mean \\
\hline Aver. area cultivated in ha (last 3 yrs) & 31837 & 23444 & 20030 & 10907 & 5815 \\
No. of tractor of $75 \mathrm{hp}$ & 98 & 91 & 104 & 92 & 84 \\
No. of tractor of $100 \mathrm{hp}$ & 1 & 1 & 40 & 15 & 5 \\
TPET & 7450 & 6925 & 11800 & 8400 & 6800 \\
TRPT & 5588 & 5194 & 8850 & 6300 & 5100 \\
Mechanization Level & 0.2 & 0.22 & 0.44 & 0.58 & 0.88 & 0.46 \\
\hline
\end{tabular}


Table 3. Estimated mechanization index for some crops in the state

\begin{tabular}{lllll}
\hline \multirow{2}{*}{ Crop/Locality } & \multicolumn{3}{c}{ Energy (MJ/ha) } & \multirow{2}{*}{ Mechanization Index } \\
\cline { 2 - 4 } & Human & Animal & Mechanical & \\
\hline Wheat & 26516.3 & 74587.2 & 7813.3 & 0.07 \\
Legumes & 34273.5 & 74587.2 & 5755.3 & 0.05 \\
Onion & 57973.6 & 66658.7 & 3779.7 & 0.03 \\
Alfalfa & 47958.8 & 74587.2 & 3772.9 & 0.03 \\
\hline
\end{tabular}

\section{Conclusion}

The Sudan have different farming sectors, it will to planning from a baseline surveys; studies result and collected information to assess the actual type and level of engineering technology for each sector, and as mechanization is a key factor for agricultural development and farmers' well-being, not only had it helped improving labor productivity many times in comparison to agriculture without mechanical power, mechanization provides also the power to ensure that agricultural operations for the soil and the plants are done precisely in time and with the highest efficiency.

The River Nile State, has a considerable arable land with low population; small size farm holding and different crops grown, which is the challenge to mechanization in the state, by wisdom it become an unrational and hardly to depend on human muscle in farm operations for stable and sustainable agricultural production in the state.

This results of the baseline survey about status of agricultural mechanization, show that the agriculture in the state still faced with the low level of mechanization, and confined only in tractorization for land preparation and stationery threshers. As the irrigated agricultural sector is essential in the Sudan for sustainable development, but agricultural productivity is largely stagnant. Which refer this to a lack and or unupdated data and information to measure the level of mechanization, for a farm, scheme, state or the whole country for suitable type of interventions. This study with the past experiences has good lessons to learn for the future development, with strengthen the weak points and enhance the positive ones.

\section{Acknowledgements}

We wish to give a great appreciation to Korea-Africa Food and Agriculture Co-operation Initiative (KAFACI), through the Rural Development Administration (RDA) of the Republic of Korea, for funding this study and technical support by attending planning meeting and workshop on agricultural mechanization to share us their great experiences.

\section{References}

Abdelrazig, E., Fatih, A. S., Abdelatif, I., \& Hassan, M. N. (2004). Sudan Poverty Reduction \& Programs in Agriculture. Report Prepared for the Food and Agriculture Organization (FAO) in Khartoum.

Adnan, A., Yang, M. L., Ehsan, E., Khurram, Y., Riaz, A., \& Tahir, I. (2017). Quantification of mechanization index and its impact on crop productivity and socio-economic factors. International Agricultural Engineering Journal, 26(3), 1.

Brian, S., \& Josef, K. (2017). Sustainable Agricultural Mechanization for Smallholders: What Is It and How Can We Implement It? Review, Agriculture, 7, 50. https://doi.org/10.3390/agriculture7060050

Cervinka, V. (1980). Fuel and energy efficiency. In D. Pimentel (Ed.), Handbook of Energy Utilization in Agriculture (pp. 15-21). CRC Press, Boca Raton, FL.

Chen, P. C., Yu, M. M., Chang, C. C., \& Hsu, S. H. (2008). Total factor productivity growth in China's agricultural sector. Journal of China Economic Review, 19, 580-93. https://doi.org/10.1016/j.chieco. 2008.07.001

FAO (Food and Agriculture Organization). (2013). Integrated crop management: Mechanization for Rural Development. A Review of Patterns and Progress From Around the World, 20.

Giles, G. W. (1975). The reorientation of agricultural mechanization for the developing countries. FAO Report on Effect of Farm Mechanization on Production and Employment. Food and Agricultural Organisation, Rome, Italy.

Government of Sudan. (2008). Excutive Summary of Executive Programme for Agricultural Revival. General Secretariat of Council of Ministers, Khartoum, Government of Sudan. 
Igbal, O. M. S., Hamid, E. B., Snežana, J., Aleksandra, D., Sinisa B., Noureddin, D., \& Vedran T. (2016). Agricultural extension and advisory system in Sudan, A review: XXI Savetovangeo Biotechlogiji. Zbornik Radova, 21(23).

Jingen, Y., \& Qishuo, D. (2000). Farm mechanization in Jiangsu province, P.R. China. Agriculutral Mechanzation in Asia, Africa and Latin America Journal, 31(1), 67-69.

Khadir, A. I., \& Adu-Hamed, N. H. (2002). The mechanization of agriculture in Jordan: Progress and Constraints. Agriculutral Mechanzation in Asia, Africa and Latin America Journal, 33(3), 51-55.

Khalid, M. M., \& Abu, R. (2013). Prospects for modernization of agriculture in Sudan with an emphasis to food security. Basic Research Journal of Agricultural Science and Review, 2(2), 39-50.

Krishnasreni, S., \& Thongsawatwong, P. (2004). Status and trend of mechanization in Thialand. Agriculutral Mechanzation in Asia, Africa and Latin America Journal, 34(1), 59-66.

Mazoyer, M. (2001). Protecting small farmers and the rural poor in the context of globalization, Rome.

Mrema, G. C., Kienzle, J., \& Mpagalile, J. (2018). Current status and future prospects of agricultural mechanization in sub-saharan Africa. Agricultural mechanization in Asia, Africa and Latin America Journal, 49(2).

NCAER (National Centre for Agricultural Mechanization). (1981). Implication of tractorisation for farm employment, productivity and income. National Council of Applied Economic Research, Parisila Bhawan, New Delhi.

Olaoye, J. O., Amusa, T., \& Adekanye, A. (2014). Evaluation of the Degree of Agricultural Mechanization Index on the Performance of Some Farm Settlement Schemes in Southwestern Nigeria (pp. 125-133). Proceedings of the International Soil Tillage Research Organisation (ISTRO) Nigeria Symposium, November 3-6, 2014, Akure, Nigeria.

Patrick, C., \& Tapela, M. (2002). A review of agricultural mechanization status in Botswana. Agriculutral Mechanzation in Asia, Africa and Latin America Journal, 33(1), 60-64.

Raheleh, F., Alizera, K., \& Seyyed, S. M. (2012). Estimation of Mechanization Index and its Impact on Energy and Economic factors in Apple Orchad in Iran. Asian Journal of Agriclture and Rural Development, 2(2), 248-259.

Rijk, A. G. (1989). Agricultural mechanisation policy and strategy, the case of Thailand. Asian Productivity Organisation, Tokyo, Japan.

Sharabiani, V. R., \& Ranjbar, I. (2008). Determination of the Degree, Level and Capacity Indices for Agricultural Mechanzation in Sarab Region. Journal of Agricultural Science Technology, 10, 215-223.

Singh, G. (2006). Estimation of Mechanization Index and its Impact on Production and Economic Factor-A case study in India. Journal of Biosystems Engineering, 93, 99-106. https://doi.org/10.1016/j.biosystemseng. 2005.08.003

Singh, G. (2001). Relationship Between Mechanization and Agricultural Productivity in Various parts of India. Agricultural Mechanization in Asia, Africa and Latin America Journal, 32(2), 68-76.

Singh, S., \& Singh, G. (1992). Energy input versus yield relationship for four major crops of Northern India. Agricultural Mechanization in Asia, Africa and Latin America, 23(2), 57-62.

Tim, L. (2007). Draft Animal Power. Retrieved from http://www.worldwideflood.com

Zeren, Y. (1991). Agricultural Inputs, Mechanization and Employment in Turkey. Agricultural Mechanization in Asia, Africa and Latin America Journal, 22(3), 63-66.

\section{Copyrights}

Copyright for this article is retained by the author(s), with first publication rights granted to the journal.

This is an open-access article distributed under the terms and conditions of the Creative Commons Attribution license (http://creativecommons.org/licenses/by/4.0/). 